\title{
Evaluation of the Association Between Lifestyle Risk Factors for Myopia Development and the Prevalence of Nearsightedness Among Young Adults
}

\section{Ocena zależności między czynnikami rozwoju krótkowzroczności związanymi ze stylem życia a częstością jej występowania wśród młodych dorosłych}

\author{
Anna Bogdali ${ }^{12}$, Jakub Jarczak ${ }^{3}$, Aleksandra Urbaniak ${ }^{3}$, Bartłomiej Ciszewski ${ }^{3}$, Natalia Mackiewicz ${ }^{3}$, \\ Bożena Romanowska-Dixon ${ }^{1,2}$ \\ Department of Ophthalmology and Ocular Oncology Jagiellonian University Medical College in Krakow \\ Head: Professor Bożena Romanowska-Dixon, MD, PhD \\ 2 Department of Ophthalmology and Ocular Oncology The University Hospital in Krakow \\ Head: Professor Bożena Romanowska-Dixon, MD, PhD \\ 3 Student Research Group at the Department and Clinic of Ophthalmology and Ocular Oncology, \\ Jagiellonian University Medical College in Krakow \\ Head: Professor Bożena Romanowska-Dixon, MD, PhD
}

Abstract: $\quad$ Aim: The aim of the study was to evaluate the association between lifestyle risk factors for myopia development and the prevalence of nearsightedness among young adults.

Materials and Methods: The analysis included 1608 students of Cracow universities. An original questionnaire was distributed to the participants through the Internet or as a paper version. Respondents answered questions about their refractive defects, average time spent per day on: reading, using electronic devices, doing- sports and staying outdoors in daylight. We also asked them about taking care of good lighting conditions, and taking breaks during visual work at close range.

Results: Our study shows the prevalence rate of vision defects, with myopia as the dominating one among Cracow's students (63\%). Our study showed an association between higher myopia prevalence and longer time spent on near work. More time spent outdoors in daylight, physical activity, and taking breaks during close work were associated with a lower frequency of nearsightedness.

Conclusion: There is a connection between some lifestyle behaviors and a higher prevalence of myopia. The development and progression of nearsightedness is a common occurrence among young adults.

Key words: $\quad$ nearsightedness, lifestyle, epidemiology, young adults.

Ahstrakt: $\quad$ Cel: Celem pracy była ocena zależności między czynnikami rozwoju krótkowzroczności związanymi ze stylem życia a częstością jej występowania wśród młodych dorosłych

Materiały i metoda: Analizą objęto 1608 studentów krakowskich uczelni wyższych. Ankietowani otrzymali oryginalny kwestionariusz w formie papierowej lub elektronicznej. Respondenci odpowiadali na pytania dotyczące wad wzroku, czasu spędzanego dziennie na czytaniu, używaniu urządzeń elektronicznych, aktywności sportowej, przebywaniu w ciągu dnia poza pomieszczeniami. Ankietowani byli również pytani o jakość oświetlenia oraz przerwy podczas pracy wzrokowej z bliskiej odlegtości.

Wyniki: W badaniu stwierdzono, że krótkowzroczność jest dominującą wadą wzroku u krakowskich studentów (63\%). Badanie wykazało związek pomiędzy wyższą krótkowzrocznością a dłuższym czasem spędzanym przy pracy z bliska. Im dłuższy czas spędzany poza pomieszczeniami, na aktywności fizycznej, im częstsze przerwy przy pracy z bliskiej odległości tym mniejsza częstość wystąpienia krótkowzroczności.

Wnioski: Istnieje związek pomiędzy stylem życia a wyższą częstością występowania krótkowzroczności.

Slowa kluczowe: krótkowzroczność, styl życia, epidemiologia, młodzi dorośli.

The authors declare no conflict of interest/ Autorzy zgłaszają brak konfliktu interesów w związku z publikowaną pracą

\section{Introduction}

Myopia is a huge, global problem with increasing prevalence rates reported all over the world. It is a condition, where the light entering the eye focuses in front of the retina instead of focusing precisely on it. Myopia occurs if the eyeball is too long or the cornea has too much curvature. Therefore, a nearsighted person sees near objects clearly, while objects in the distance are blurred. Nearsightedness is the most common refractive er- 
ror of the eye, which currently affects almost 2 billion people, so nearly $30 \%$ of the human population (1). The highest prevalence of myopia is observed among students in highly developed Asian countries, where it reaches up to $97 \%$ of the postgraduate university students in Shanghai, China, or over $80 \%$ in high-school students in Beijing, China. An extremely high frequency of nearsightedness is also observed among students in Japan, Singapore and Taiwan $(2,3,4)$. Far fewer publications on the issue concerns Europe. Perhaps this is because the defect is rarer on the European continent than in Asia. Nonetheless, in Europe, the incidence of myopia is constantly growing (1). A good example of this phenomenon is the result of a study which compared the change in myopia prevalence among Portuguese first-year university students in 2002 and 2014 at the University of Minho. The prevalence of myopia in 2002 was $23.4 \%$ as compared to $41.3 \%$ in 2014 (5). Polish studies mainly focus on myopia in children, and a very small number of studies refer to its development and progression in adults. In 2007, the prevalence of myopia among 18-year-old pupils in Poland was $32.6 \%$, while several decades earlier, it was $12-15 \%(6,7)$. In a 2005 study involving Polish medical students in Szczecin, the prevalence of myopia among the students of the second year was $42 \%$, and after 2 years, it increased to $51 \%(7)$. In literature, lifestyle behaviors are increasingly identified as the cause of development and progression of nearsightedness. These include long-term visual work from a close distance, and no rest periods for the eyes during such work, lack of physical activity, or short time spent outside in daylight $(2,4,8,9,10)$. The purpose of this study was to evaluate the association between lifestyle risk factors for myopia development and the prevalence of nearsightedness among students of the Cracow universities.

\section{Material and Methods}

An original questionnaire was created for the purpose of our study. The questionnaire was distributed through the Internet as well as in a paper version among students (at least 18 years old) of the major universities of Cracow. From March 2016 to April 2016, we collected 1670 answers, out of which we rejected 62, which had been incorrectly filled out. Therefore, 1608 questionnaires were included in the further analysis. The analyzed universities were characterized by different profiles. The collected questionnaires were completed by students of the following universities:

AGH University of Science and Technology (AGH) - 207 answers,

University School of Physical Education (AWF) - 204 answers, Cracow University of Technology (PK) - 211 answers,

Jagiellonian University (UJ) - 322 answers,

Jagiellonian University Medical College (UJ CM) - 321 answers,

University of Agriculture in Cracow (UR) - 214 answers,

Other Universities - 129 answers.

$68 \%$ of the respondents were females, and $32 \%$ were males. The mean age of the respondents was 22.2. Respondents answered questions about their refractive defects, average time spent per day on: reading, using electronic devices at a distance less than $1 \mathrm{~m}$, doing sports, and staying outdoors in daylight. We also asked them about paying attention to good lighting conditions, and taking breaks during reading from close distance. To verify the impact of lifestyle risk factors for myopia development we distinguished 2 groups among all respondents. The first one included people with myopia, and the second one people without any vision impairment. We compared the two groups for exposure to the risk factors. Statistical analysis was prepared with the use of the IBM SPSS software, version 24. The original data was shown on percentage bars or pie charts. For a comparison of percentage distribution between groups such as "myopia" and "without vision defect," a chi-squared test or Fisher's exact test (if necessary) were used. Due to the differences between the groups, and many categories within questions, a ROC curve analysis was used to determine the cut-off point for each variable, reporting additionally AUC with $95 \%$ $\mathrm{Cl}$ and $\mathrm{p}$-value. Univariate logistic regression models were created only for the variables that proved significant in ROC analysis. A multivariate logistic regression model was made, after checking the correlation of the predictors, and excluding one of them (time spent outdoors in daylight). Results are presented with $\mathrm{OR}$ values with $95 \% \mathrm{Cl}$ and $\mathrm{p}$. For all calculations, the significance level $\alpha=0.05$ was assumed.

\section{Results}

Our study shows that the mean prevalence of vision defects among Cracow's students is $63 \%$. Probably it is a little higher, as some of the $5 \%$ of respondents who answered "I don't know" suspected a defect in themselves, but they had not been diagnosed yet. The remaining $32 \%$ respondents answered "no, I do not have vision defect".

The most significant vision impairment burden applies to UJ CM students, out of which more than $77 \%$ have a vision defect. The lowest rate of vision impairment was found among AWF students, out of which only $42 \%$ have vision impairment (Figure 1).

\section{The presence of vision defects}

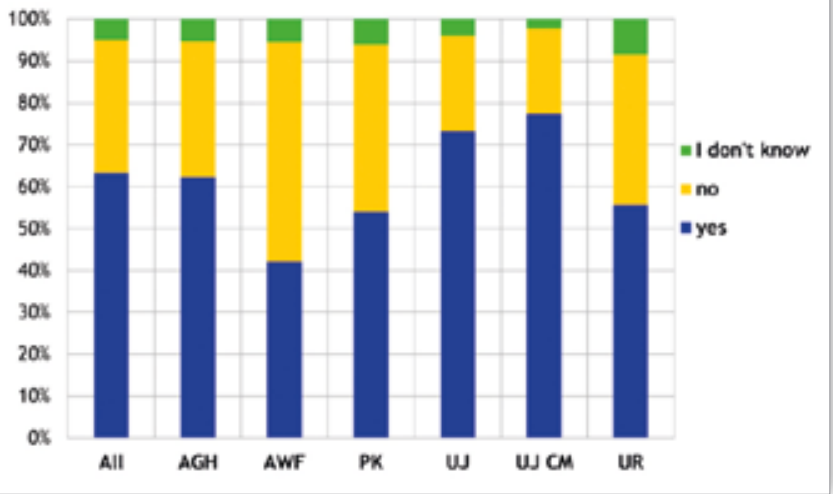

Fig. 1. The presence of vision defects at different universities. Ryc. 1. Występowanie wad wzroku na różnych uniwersytetach.

With myopia as the prevailing one, the prevalence of each defect is comparable among all universities (Figure 2).

The frequency of refractive errors decreases with the increase of the plus or minus correction value. The overwhelming majority is myopia (Figure 3).

The respondents were also asked to describe how their vision quality had changed since the beginning of studies. It turned out that $51 \%$ of the questioned students complained 


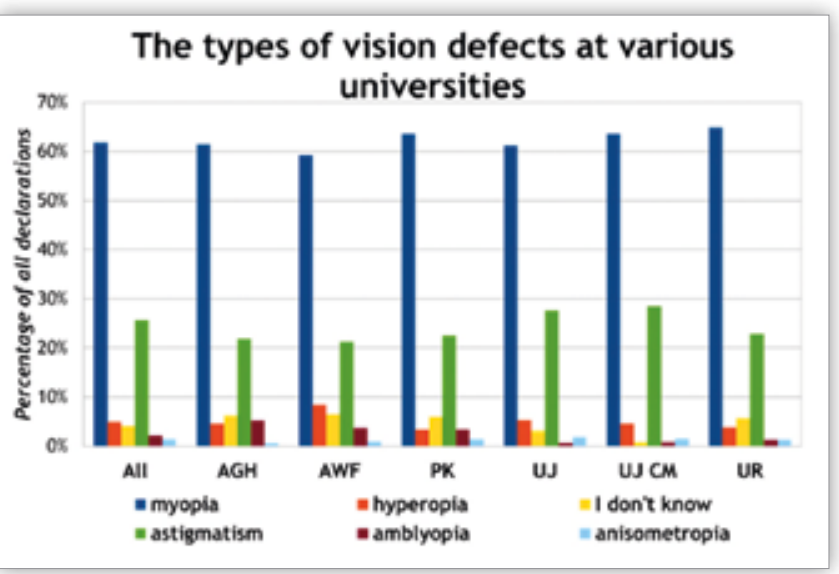

Fig. 2. The types of vision defects at various universities.

Ryc. 2. Rodzaje wad wzroku na różnych uniwersytetach.

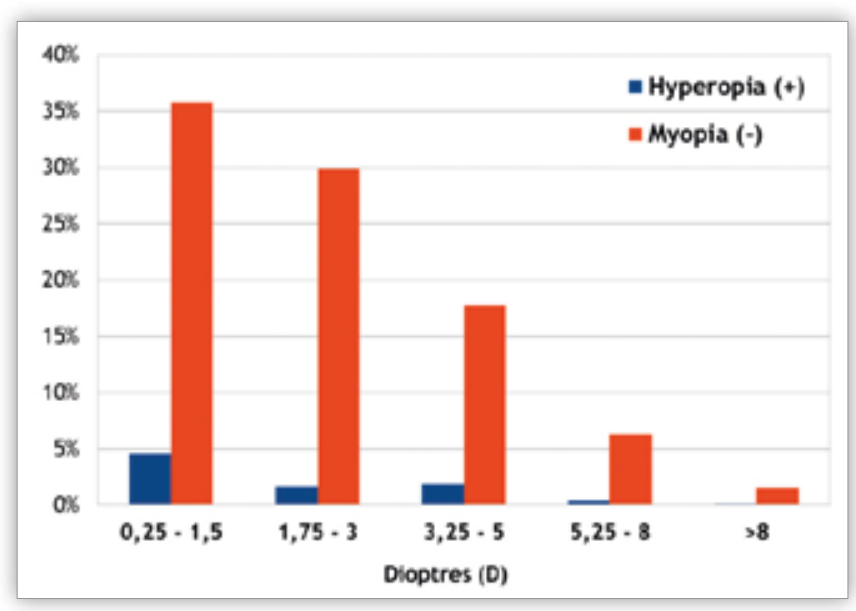

Fig. 3. Declared value of vision defect.

Ryc. 3. Deklarowana wartość wady wzroku.

about poorer eyesight than at the beginning of the university. $41 \%$ of the respondents did not observe any changes, $7 \%$ answered "it's hard to say" and 1\% noticed an improvement in vision quality. The majority of people with poor eyesight (33\%) had noticed their vision deterioration in primary school for the first time. $24 \%$ of the questioned noticed their vision deterioration in secondary school, $19 \%$ in high school and $6 \%$ in preschool. $14 \%$ of the respondents declared that their vision had deteriorated only during their university studies. For $4 \%$ asked people vision impairment was congenital.

To verify the impact of lifestyle risk factors for myopia development we distinguished two groups among all respondents. The first one included 830 people (51.6\%) with myopia, and the second included 511 people (31.8\%) without any vision defect. We compared the two groups for exposure to the risk factors.

$67.7 \%$ of the respondents were females, and $32.3 \%$ were males. Our study shows that sex does matter, because shortsightedness is more common in women than in men. Among people with myopia, $73 \%$ were females and $27 \%$ were males. Among people without vision defect $59.1 \%$ were females and $40.9 \%$ were males $(p<0.001)$.

Visual work from close distance is more and more commonly considered as one of the risk factors for the myopia development. We asked the respondents to state how much time per day they spend on reading books, newspapers, notes, etc. My- opic people spent on reading per day the following amount of time: $<1 \mathrm{~h}-8.1 \%, 1-2 \mathrm{~h}-24.5 \%, 3-4 \mathrm{~h}-35.9 \%, 5-6 \mathrm{~h}-19.3 \%$, $7-8 \mathrm{~h}-6.9 \%,>8 \mathrm{~h}-5.4 \%$. People without vision defect spent on this activity $<1 \mathrm{~h}-8.4 \%, 1-2 \mathrm{~h}-34.2 \%, 3-4 \mathrm{~h}-32.3 \%, 5-6 \mathrm{~h}$ $-15.5 \%, 7-8 \mathrm{~h}-5.1 \%,>8 \mathrm{~h}-4.5 \%$, respectively. We received results indicating that short-sighted people spend more time reading than people without a vision defect ( $p=0.005$ ).

We also asked our respondents about a habit of taking a few minutes breaks, consisting in closing one's eyes, and looking into the far distance during long-term visual work at close distance (at least once every 40 minutes). 11.7\% people with myopia answered this question "yes", 23.4\% "rather yes", $15.4 \%$ "hard to say", $37.1 \%$ "rather no" and $12.4 \%$ answered "no". People without vision defect responded respectively: "yes" - 14.7\%, "rather yes" - 29.0\%, "hard to say" - $15.1 \%$, "rather no" - 29.5\%, "no" - 11.7\%. It turned out that people without vision impairment remembered about those breaks for their eyes more often than people with myopia ( $p=0.021$ ).

Another risk factor for the development of nearsightedness is the lack of sport activity. Our study shows a strong relationship between the time spent on physical activity and the incidence of myopia. The shorter the time spent on sport activities, the greater the incidence of myopia (Figure 4).

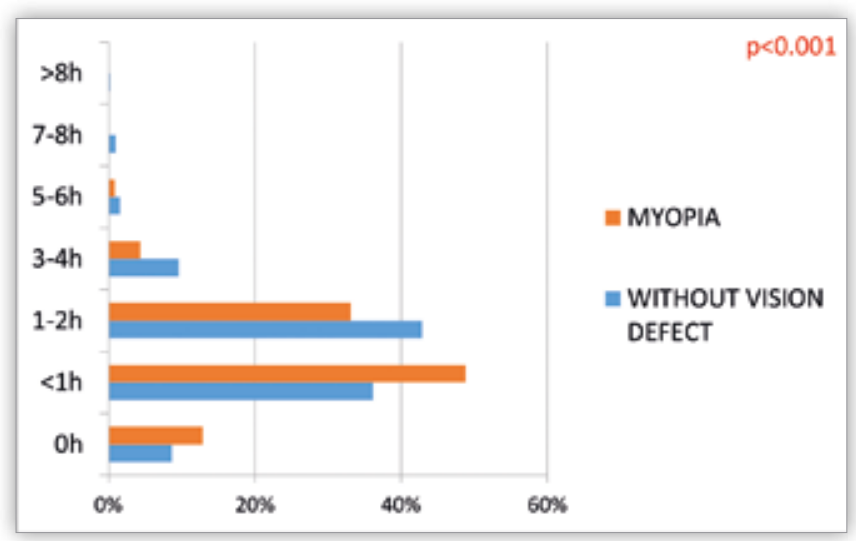

Fig. 4. Time spent on sport and other physical activities per day.

Ryc. 4. Czas spędzany na uprawianiu sportu i innych aktywnościach fizycznych w ciągu doby.

A long time spent outdoors in daylight is considered as a factor that prevents the development of myopia. Myopic people spent outdoors in daylight per day $<1 \mathrm{~h}-30.0 \%, 1-2 \mathrm{~h}-$ $56.0 \%, 3-4 \mathrm{~h}-12.7 \%, 5-6 \mathrm{~h}-1.0 \%, 7-8 \mathrm{~h}-0.2 \%,>8 \mathrm{~h}-0.1 \%$. People without vision defect spent outdoors $<1 \mathrm{~h}-20.4 \%$, $1-2 \mathrm{~h}-51.1 \%, 3-4 \mathrm{~h}-24.1 \%, 5-6 \mathrm{~h}-3.7 \%, 7-8 \mathrm{~h}-0.8 \%,>8 \mathrm{~h}-$ $0.0 \%$, respectively. In our study, the influence of the mean time spent outdoors in sunlight per day was statistically significant $(p<0.001)$. Myopic people spent less time outside than people without vision defects.

Interestingly, we did not observe a statistically significant association between a longer use of electronic monitors at close distance (less than 1 meter) and a greater prevalence of shortsightedness ( $p=0.695$ ). The results showed that people with myopia used electronic monitors at close distance per day: $<1 \mathrm{~h}-1.3 \%, 1-2 \mathrm{~h}-9.0 \%, 3-4 \mathrm{~h}-36.3 \%, 5-6 \mathrm{~h}-31.8 \%$, $7-8 \mathrm{~h}-11.2 \%,>8 \mathrm{~h}-10.4 \%$. Respondents without vision defect used electronic monitors at close distance $<1 \mathrm{~h}-1.4 \%, 1-2 \mathrm{~h}$ 
$-11.4 \%, 3-4 \mathrm{~h}-33.5 \%, 5-6 \mathrm{~h}-30.5 \%, 7-8 \mathrm{~h}-12.3 \%,>8 \mathrm{~h}-$ $11.0 \%$, respectively.

Similarly, paying attention to good lighting conditions during visual work from close range also turned out to have no effect on the incidence of myopia $(p=0.168)$. To the question "do you take care for good lighting during visual work from close range?" $33.4 \%$ of myopic people answered "yes", $43.0 \%$ "rather yes", $11.3 \%$ "hard to say", $10.7 \%$ "rather no" and $1.6 \%$ answered "no". People without vision defect responded to the same question "yes" $33.3 \%$, "rather yes" $38.9 \%$, "hard to say" $11.0 \%$, "rather no" $14.1 \%$, "no" $2.7 \%$, respectively.

The designated cut-off points for ROC analysis are presented in the table below - only for the statistically significant results. Logistic regression was performed for variables categorized by cut-off points.

Reading for 3 hours and more results in a 1.5 odd ratio for having myopia. Doing sports for less than an hour almost doubles the chance of myopia. Staying outdoors for less than an hour increases the risk of myopia by 1.7 times. No breaks during visual work at close range result in a 1.4-fold increase in the risk of myopia (Table 1). ped Asian countries such as China, Taiwan, Japan or Singapore, where the frequency is even more than $90 \%(3,4)$. However, this should not, in any case, be a source of optimism for us, because when analyzing earlier Polish studies, we observed a very rapid increase in the incidence of that particular vision defect $(6,7)$.

Our study showed that there was a connection between some lifestyle behaviors and a higher prevalence of myopia. We received results that are similar to the majority of studies devoted to the phenomenon $(4,11)$.

The first risk factor, but not directly connected with lifestyle is the female sex. Similarly to other studies, we observed greater exposure of women to myopia. Perhaps it is not related so much with sex, but with a lifestyle that favors the development of myopia, which is more common in women than in men. It is worth subjecting that thesis to further analyses.

In our study, reading was another factor associated with a higher prevalence of myopia. In the questionnaire, we asked about reading books, newspapers or study notes. The study showed that visual work from near distance favors the development and progression of myopia. That result is consistent with other studies $(4,12)$.

\begin{tabular}{|l|c|c|c|c|c|c|}
\hline & AUC & $\mathbf{9 5 \%}$ CI for AUC & $\mathbf{p}$ & Cut-off category & ORinterpretation & 95\% CI for OR \\
\hline Reading & 0.553 & $0.522-0.585$ & 0.001 & $3-4 \mathrm{~h}$ & $1.543 \geq 3 \mathrm{~h}$ & $1.229-1.938$ \\
\hline Using electronic screens & 0.500 & $0.467-0.532$ & 0.976 & & \\
\hline Sport and other physical activities & 0.596 & $0.565-0.628$ & $<0.001$ & $<1 \mathrm{~h}$ & $1.983<1$ & $1.585-2.479$ \\
\hline Time spent outdoors in daylight & 0.594 & $0.562-0.625$ & $<0.001$ & $1-2 \mathrm{~h}$ & 1.677 & $1.291-2.179$ \\
\hline Breaks during long-term visual work & 0.545 & $0.513-0.577$ & 0.006 & Hard to say & $1.434 \mathrm{NO}$ & $1.145-1.797$ \\
\hline Taking care of good lighting conditions & 0.517 & $0.485-0.550$ & 0.287 & & & \\
\hline
\end{tabular}

Tab. I. Results of ROC analysis and significant univariate logistic regression models for the evaluation of myopia.

Tab. I. Wyniki analizy ROC oraz istotne jednoczynnikowe modele regresji logistycznej dla oceny krótkowzroczności.

Multivariate logistic regression model for myopia includes reading, sport and breaks. For that model, we obtained $64 \%$ of the correct qualifications, which means that $64 \%$ of those variables describe myopia. Time spent outdoors was associated with doing sports and taking breaks, therefore we didn't include it in the process of creating the model (Table 2).

\begin{tabular}{|l|c|c|c|}
\hline & OR & $\mathbf{9 5 \%}$ Cl for OR & p \\
\hline Reading $\geq \mathbf{3 h}$ & 1.572 & $1.246-1.982$ & $<0.001$ \\
\hline $\begin{array}{l}\text { Sport and other physical } \\
\text { activities < }\end{array}$ & 1.971 & $1.537-2.470$ & $<0.001$ \\
\hline $\begin{array}{l}\text { Breaks during long-term } \\
\text { visual work N0 }\end{array}$ & 1.459 & $1.159-1.837$ & 0.001 \\
\hline
\end{tabular}

Tab. II. Multivariate logistic regression model for myopia.

Tab. II. Wieloczynnikowy model regresji logistycznej dla krótkowzroczności.

\section{Discussion}

The frequency of the refractive error known as myopia is $63 \%$ among the students of Cracow, and it is definitely the most prevalent defect in that population. Myopia occurs among Cracow's students less often than among students in highly develo-
With respect to visual work from a close distance, we also asked about the time spent using electronic screens from a distance less than 1 meter. To our surprise, the dependence was not statistically significant. We suspect that this may be due to the fact that people who read a lot of papers spend less time using electronic devices. However, the total time of close work is still longer in that group than in people using electronic screens for longer time.

Taking a few minutes' breaks consisting in closing one's eyes and looking far into the distance during long-term visual work at close range, at least once every 40 minutes, turned out to be a protective factor for the development and progression of myopia. Some researchers reported that the lack of breaks was a more important risk factor for the development of myopia than visual work at close distance (12). It should be noted that the factor is easy to modify.

Our study showed a strong relationship between a shorter time spent on physical activities and a greater incidence of myopia. Sport activities seem to reduce the risk of myopia. Unfortunately, we did not ask our respondents, whether physical activity was performed indoors or outdoors. This is important in relation to the next risk factor we enquired about, i.e. the time spent outdoors in daylight. 
In our study, we observed that the average time spent outdoors in sunlight per day was linked to myopia. Our results were statistically significant. Myopic people tend to spend less time outdoors than people without vision defects. Shah et al. also showed similar results to our study. In their study, the time spent outdoors during childhood was found to be protective against myopia (Shah et al. 2017).

As children we were told many times to pay attention to good lighting conditions while reading after dark. We decided to check, whether that recommendation was relevant by asking respondents, whether they paid attention to good lighting during their visual work from close distance. In our study, we did not observe a significant relationship between good lighting and the frequency of myopia. However, the term "good lighting" was not specifically defined, and the answers were based on the respondents' subjective feelings. We have not found any papers in the literature that would indicate an influence of reading in low light on the development of myopia.

It is believed that acquired myopia starts to appear during school time, and its value stabilizes around the age of 20 . We decided to check it on the basis of the studied population. The biggest part of respondents, who have poor eyesight, noticed their vision deterioration in primary school for the first time. However, it is worth noting that in $14 \%$ of students visual impairment emerged in adulthood, after the start of university. The respondents were also asked to describe how their vision quality had changed since the moment they started university. More than half of the respondents see worse now than at the beginning of their studies. On the basis of those results, it seems that myopia may appear and progress after the age of 20 , and that is a common phenomenon. In the literature, we have not found studies showing the frequency of myopia that first appears and progresses in adults.

One of the reasons we did our research was out of curiosity, whether the incidence of vision defects was different at universities with varied profiles. The results showed a large difference in the occurrence of short-sightedness between universities with different profiles. Over $77 \%$ of students of the Jagiellonian University Medical College (UJ CM) declared a vision defect. For comparison, only $42 \%$ of those studying at the University School of Physical Education (AWF) reported a vision impairment. The chosen course of study often greatly determines the student's lifestyle, which may prevent or induce a deterioration of vision. We have to keep in mind that the type of study program usually tells us a lot not only about the student's current lifestyle, but also about their past.

In the literature, we did not find similar attempts to compare students of different universities with each other.

In summary, there is a connection between some lifestyle behaviors and a higher prevalence of myopia. The development and in particular progression of shortsightedness is a common occurrence among young adults. The global increase of myopia prevalence is mainly due to the development of our civilization, which is directly linked to increased educational requirements, longer time spent on visual work at close range, and an increasingly sedentary lifestyle.

\section{References}

1. Holden BA, Fricke TR, Wilson DA, Jong M, Naidoo KS, Sankaridurg P, et al.: Global Prevalence of Myopia and High Myopia and Temporal Trends from 2000 through 2050. Ophthalmology, 2016; 123(5): 1036-1042.

2. Czepita D: Krótkowzroczność - występowanie, patogeneza, postępowanie. Prz Okul. 3/2015.

3. Sun J, Zhou; J, Zhao P, Lian J, Zhu H, Zhou Y, et al.: High Prevalence of Myopia and High Myopia in 5060 Chinese University Students in Shanghai. Invest Ophthalmol Vis Sci., 2012; 53: 7504-7509.

4. Wu LJ, You QS, Duan JL, Luo YX, Liu LJ, Li X, et al.: Prevalence and Associated Factors of Myopia in High-School Students in Beijing. PLoS One, 2015; 10(3).

5. Jorge J, Braga A, Queirós A: Changes in Myopia Prevalence among First-Year University Students in 12 Years. Optom Vis Sci., 2016; 93(10): 1262-1267.

6. Czepita D, Żejmo M, Mojsa A: Prevalence of myopia and hyperopia in a population of Polish schoolchildren. Ophthal Physiol Opt. 2007 27: 60-65.

7. Mozolewska-Piotrowska K, Stępniewska J, Nawrocka J: Frequency and incidence of myopia among medical students. Klin Oczna. 2005; 107(7-9): 468-470.

8. Czepita D, Mojsa A, Ustianowska M, Czepita M, Lachowicz E: Reading, writing, working on a computer or watching television, and myopia. Klin Oczna. 2010; 112(10-12): 293-295.

9. Fernández-Montero A, Olmo-Jimenez JM, Olmo N, Bes-Rastrollo M, Moreno-Galarraga L, Moreno-Montañés J, et al.: The impact of computer use in myopia progression: a cohort study in Spain. Prev Med. 2015; 71: 67-71.

10. Shah RL, Huang Y, Guggenheim JA, Williams C: Time Outdoors at Specific Ages During Early Childhood and the Risk of Incident Myopia. Invest Ophthalmol Vis Sci. 2017 58(2): 1158-1166.

11. Czepita M, Kuprjanowicz L, Masternak T, Jadowska E, Czepita D: Contemporary Opinion on the Myopia Pathogenesis. Kontaktol Opt Okul. 4/2013: 5-7.

12. Ip JM, Saw SM, Rose KA, Morgan IG, Kifley A, Wang JJ, et al.: Role of near work in myopia: findings in a sample of Australian school children. Invest Ophthalmol Vis Sci. 2008; 49(7): 2903-2910 .

The paper was originally received 18.12.2018 (KO-00190-2018)/ Praca wpłynęta do Redakcji 18.12.2018 (KO-00190-2018) Accepted for publication 03.06.2019/

Zakwalifikowano do druku 03.06.2019.

Reprint requests to (Adres do korespondencji):

dr n. med. Anna Bogdali

ul. Kopernika 38

31-501 Kraków

annabogdali@poczta.onet.pl

phone: +48 502169602 